\title{
A retrospective review of specialist referrals for refugees into Greece's health system: A humanitarian organization's perspective
}

\author{
Vanessa Yarwood, Meghan Gunst' ${ }^{1}$, Christine Yen-Ting Chen², Kate Jarman , Sakib Rokadiya4, Majd Isreb5 , Aula Abbara5,6 \\ Lewisham and Greenwich NHS Trust, London, UK, ${ }^{1}$ Sydney Children's Hospital Network, Australia, ${ }^{2}$ Mount Sinai St Luke's-West Hospital Center, \\ New York, NY, USA, ${ }^{3}$ Norwegian Red Cross, Norway, ${ }^{4}$ Bart's Health NHS Healthcare Trust, London, UK, ${ }^{5}$ Syrian American Medical Society, \\ Washington, DC, USA, ${ }^{6}$ Imperial College, London, UK
}

\begin{tabular}{|c|}
\hline Access this article online \\
\hline Website: www.avicennajmed.com \\
\hline DOI: 10.4103/ajm.ajm_136_20 \\
\hline Quick Response Code: \\
$\square$
\end{tabular}

\section{ABSTRACT}

Aim: Refugee arrivals to Europe have numbered more than one million since 2015 with the majority arriving through Greece. The healthcare needs of refugees have placed strains on Greece's healthcare system which has already been affected by its ongoing economic crisis. At the peak of arrivals during 2016, primary healthcare was primarily provided by humanitarian organizations with specialist referrals into the Greek healthcare system. There is little published literature on the type and impacts of specialist referrals for refugees in Greece. The aim of this retrospective review is to identify the type and impacts of specialist referrals for refugees into Greece's health system. Methods: This retrospective study reviewed the number and type of specialty referrals from one humanitarian organization providing primary healthcare for refugees in Greece. All consultations during an 8-month period (December 1, 2016-July 31, 2017) were reviewed. Results: Of 4168 consultations, $42 \%$ were patients aged 17 years or younger, $52 \%$ were male, and $90 \%$ were Syrian. Two hundred and thirty-three patients (11\%) required a specialist referral; $25 \%$ were for dental (provided by another humanitarian organization), $10 \%$ each for obstetrics and gynecology and pediatrics, and $8 \%$ for ophthalmology. Respiratory complaints were most frequently seen, and these were more predominant in the winter months. Pediatric consultations varied according to month, likely due to population movements. Conclusion: Dentistry was noted to be a gap in humanitarian response programming and accounted for the greatest need for specialist input with referrals for women and children accounting for a large proportion of referrals.

Key words: Dental, Greece, health system primary care, refugee health, specialist care, Syria

\section{BACKGROUND}

Greece's economic crisis has affected healthcare access for its own population with increasingly privatized services necessary to fill gaps resulting from inadequate public healthcare services, resulting in out-of-pocket expenditure for Greek citizens being among the highest in Europe and contributing to increasing economic inequalities. ${ }^{[1]}$ The health system has been further affected by the arrival of more than one million refugees, most of whom are fleeing

Address for correspondence: Dr. Vanessa Yarwood,

Queen Elizabeth Hospital, Stadium Road, Woolwich,

London SE18 4QH, UK.

E-mail: vanessa.yarwood1@nhs.net conflicts in Syria, Iraq, and Afghanistan. ${ }^{[2]}$ In March 2016, closure of the Greece-FYROM (former Yugoslav Republic of Macedonia) border and the EU-Turkey deal blocked transit routes leaving around 50,000 refugees in Greece. ${ }^{[3]}$ As of December 2020, there are 119,000 refugees in Greece. ${ }^{[4]}$

This is an open access journal, and articles are distributed under the terms of the Creative Commons Attribution-NonCommercial-ShareAlike 4.0 License, which allows others to remix, tweak, and build upon the work non-commercially, as long as appropriate credit is given and the new creations are licensed under the identical terms.

For reprints contact: reprints@ @edknow.com

Cite this article as: Yarwood V, Gunst M, Chen CY, Jarman K, Rokadiya $\mathrm{S}$, Isreb $\mathrm{M}$, et al. A retrospective review of specialist referrals for refugees into Greece's health system: A humanitarian organisation's perspective. Avicenna J Med 2021;11:84-92. 
The provision of healthcare to refugees in Greece has presented financial, logistical, ${ }^{[5]}$ as well as language and cultural challenges ${ }^{[6]}$ to both humanitarian organizations and the Greek health system. In 2017, $41.7 \%$ of refugees were from Syria, $19.6 \%$ from Iraq, and 11.6\% from Afghanistan. ${ }^{[3]}$ In February 2020, of the 40,750 refugees residing on Greek islands, $49 \%$ are Afghani, $19 \%$ are Syrian, and 6\% are Somali ${ }^{[7]}$ with inadequate numbers of translators causing further strains. ${ }^{[5]}$

Healthcare for refugees and asylum seekers in Greece is free at point of access under Greek law through the national health system. ${ }^{[8]}$ However, increased numbers of refugees overwhelmed the system, and primary healthcare (PHC) was increasingly provided by humanitarian organizations, ${ }^{[9]}$ some with a focus on specialist provision. ${ }^{[10]}$ Refugees could access secondary care services once they had a social security number (called an AMKA); however even for Greek citizens, secondary healthcare could be costly. ${ }^{[5,1]}$ Recent policy has made access to AMKA more restrictive and as of July 2019, many refugees in Greece are unable to access non-emergent care. ${ }^{[6,12]}$

\section{Role of humanitarian organizations}

Humanitarian organizations predominantly provide $\mathrm{PHC}$ services, with referrals into the Greek health system for specialist care and investigations ${ }^{[5]}$ Healthcare provision for refugees is affected by geographical, logistical, and linguistic constraints as well as frequent changes to local and regional policies. ${ }^{[13]}$ Weak coordination mechanisms contribute to gaps in services particularly for vaccinations, dental, mental health and psychosocial services (MHPSS), and maternal, newborn, and child health $(\mathrm{MNCH}) .^{[5,11,14]}$

While some prevalent conditions are similar to those of the host population, e.g. non-communicable diseases (NCDs) and $\mathrm{MNCH}$, fragmented populations with different cultural and linguistic backgrounds provide unique healthcare challenges. MHPSS needs among refugee populations differ from host populations due to experiences of conflict and trauma both prior to commencing the journey and during transit, compounded by political and community responses once reaching host countries. ${ }^{[10]}$

Delivering a timely service with adequate follow-up and support to vulnerable groups was challenging for humanitarian organizations. ${ }^{[1,14,15]}$ Changes to funding streams and policies ${ }^{[16]}$ led to closure of projects across Greece due to high operational costs and reduced direct funding. Government representatives formed agreements with humanitarian organizations to provide PHC, while referrals into the Greek health system for secondary care were developed in an often ad hoc manner. ${ }^{[13]}$ Other organizations provided specialist services including MHPSS, dentistry, and $\mathrm{MNCH}$ as stopgap solutions. Daily reporting of infectious diseases to KEELPNO, the Hellenic Centre for Disease Control and Prevention, the Greek equivalent to the CDC, was mandatory. ${ }^{[17,18]}$

It is on the background of these changes that we analyze retrospective, routinely collected data from $\mathrm{PHC}$ consultations at clinics in northern Greece run by the Syrian American Medical Society (SAMS). Our main aim was to identify the most prevalent presentations requiring referral outside of this organization with the aim of highlighting programming needs for refugees in light of these findings.

\section{MATERIALS AND METHODS}

\section{Study setting}

SAMS is a US-based humanitarian organization that provided PHC in Greece. The model of care is based on international volunteer medical staff and interpreters providing consultations in a range of informal and formal camps across Greece. Medical specialties of volunteers included general practice, emergency medicine, pediatrics, obstetrics and gynecology, and internal medicine, aiming to provide certain specialist consultations in-house and prevent referrals into the Greek healthcare system. A thorough vetting process was enforced and clinicians with at least 3 years postgraduate training were selected with the majority of staff from Europe, the USA, and Australia, a minority of whom spoke Arabic or Kurmanji, whereas others relied on interpreters. Camp coordination meetings were attended to raise issues and ensure open lines of communication, and pathways were set up with other actors who delivered specialist services, and with facilities for blood tests and radiology services. SAMS obtained permissions from the Greek Ministry of Health $(\mathrm{MOH})$ to provide medical care in the camps assigned.

During the period of study (December 2016 to July 31, 2017), SAMS was active in multiple locations, mostly within $100 \mathrm{~km}$ of each other, as Figure 1 highlights. The total catchment of refugees served varied due to relocation and closure of camps; Greek MOH data estimated 500-600 refugees in each of these camps. ${ }^{[19]}$

\section{Data management}

Clinicians received training regarding inputting of data from consultations into the electronic health database; data were reviewed to ensure best practice and support consistency. The electronic health database was available in each clinic on a password-protected device with patient registration/ demographic and clinical domains. 


\section{Data collection}

All patient consultations within the period studied were obtained from the electronic database. Demographic and clinical data were extracted retrospectively after permission was gained from SAMS. The data was encrypted and anonymized.

\section{Data analysis}

After de-identification, data were imported into IBM SPSS Statistics for Macintosh, version 24 (IBM Corp., Armonk, NY, USA) to identify monthly trends across the locations in age groups. Incomplete charts were analyzed to the extent of each complete variable. No active recruitment of additional patients was conducted for this retrospective programmatic analysis. The data were descriptive and focussed on trends and proportions.

\section{Ethics}

Institutional Review Board approval was granted by the Columbia University Administrative Review Committee.

\section{RESULTS}

\section{Demographics}

There were 4168 consultations; 2171 male and 1997 female who were undertaken between December 1, 2016 and July
31, 2017, which included repeat visits. About 880 (21.1\%) consultations were for those under 5 years ( $61.4 \%$ male), 876 (21\%) visits were for those aged 5-17 years (50.1\% male), 2376 (57\%) visits were for those aged 18-65 years (49.6\% male), and $36(0.9 \%)$ visits were 66 years and older $(41.7 \%$ male). About $89.7 \%$ of the consultations were for Syrian patients with the other main nationalities being Iraqi and Afghani; $88.5 \%$ of the patients spoke Arabic and $51.2 \%$ of the patients spoke Kurdish; these patients originated from Syria and Iraq. Figure 2 shows the population histogram by gender and age group. Table 1 (see appendix) shows the number of consults for each age group by month.

The number of consultations delivered fell during the first few months of 2017 due to population movements as were gradually closed and SAMS relocated to provide PHC for refugees at other locations.

\section{Presenting complaints}

Figure 3 shows the total consultations according to the presenting complaint. Table 2 (see appendix) shows the consultations according to presenting complaint for each month. The main complaints were acute infections (29\% of consultations over the period); these were primarily respiratory infections which were presumed to be

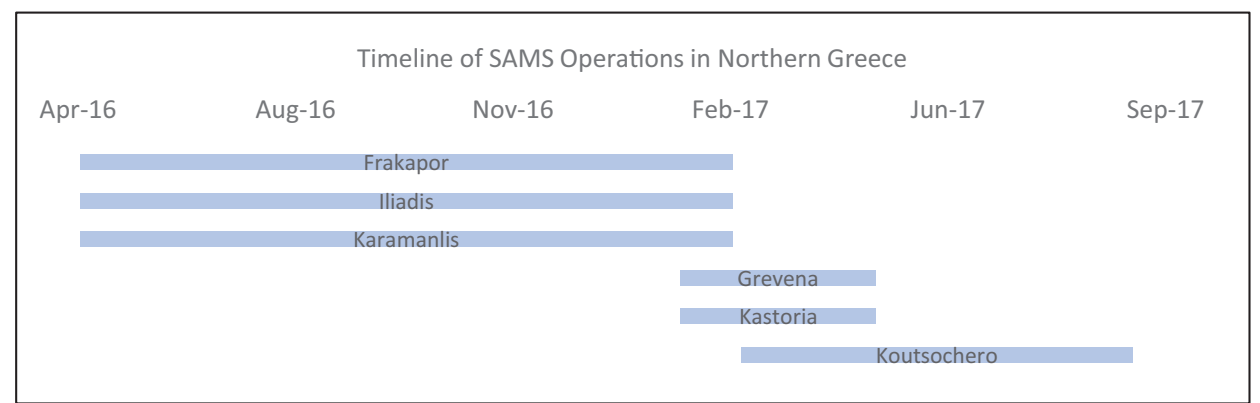

Figure 1: Location of primary healthcare clinics run by SAMS in northern Greece between April 2016 and September 2017. From April 2016 to February 2017, we provided primary healthcare in Frakapor, Iliadis, and Karmanlis but when they closed, we moved to provide primary healthcare services in the other sites noted

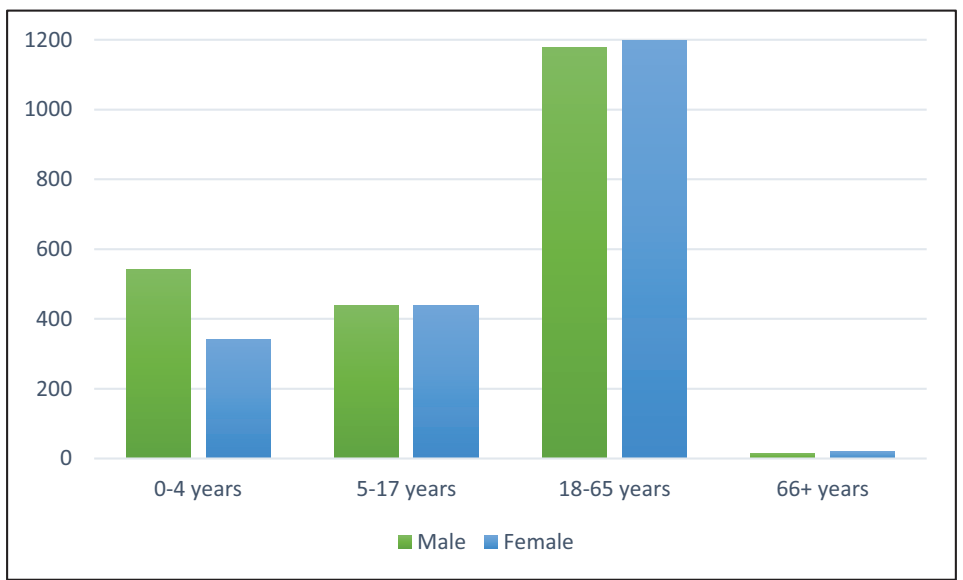

Figure 2: A population chart showing the breakdown of age groups according to gender for patients who received primary healthcare consultations in the SAMS clinics during the study period 
viral or bacterial, skin/soft tissue infections (including infected insect bites and parasitic infestations such as scabies), and gastrointestinal (food-related or viral). Chronic complaints (25\% of the consultations) included musculoskeletal, neurological complaints (e.g. headaches, chronic pain), and some non-communicable diseases (e.g. hypertension, diabetes, pregnancy, and mental health). The "other" category (14\%) includes the summation of those who presented to healthcare services for reasons such as blood tests, those who did not wait to be seen, required paperwork, or were enquiring after referrals; $5.4 \%$ of consultations were for medication refills and check-ups. Due to frequent population displacement in the area and changes to clinics made by service planners, short-term prescriptions for chronic conditions were dispensed to avoid wastage, as follow-up for these patients was often disrupted.

\section{Diagnosis}

Figure 4 shows the specialty that the consultation was recorded under, with Table 3 (see appendix) charting this information per month.

Respiratory presentations were most common, accounting for just over a fifth overall, with respiratory tract infections and chronic obstructive airways disease prevalent in this population. Skin and soft tissue complaints were the second most common diagnostic category seen; this covered scabies, wound infections developing from minor injuries, and dermatitis conditions. Another prevalent diagnostic

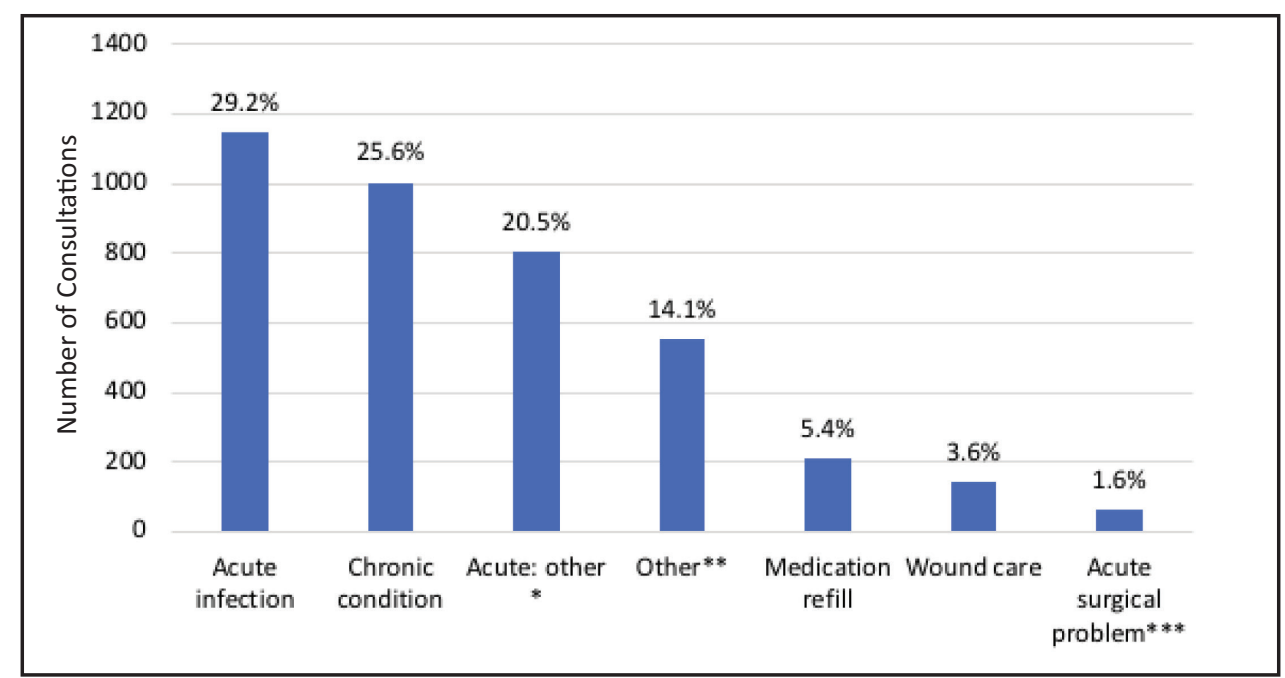

Figure 3: Consultation numbers according to presenting complaint. *Acute other: acute complaints that are not infections and not surgical. **'Other includes: blood tests, left before seeing clinician, paperwork required, chasing referrals. ${ }^{\star \star \star}$ Acute surgical problem also includes surgical complications

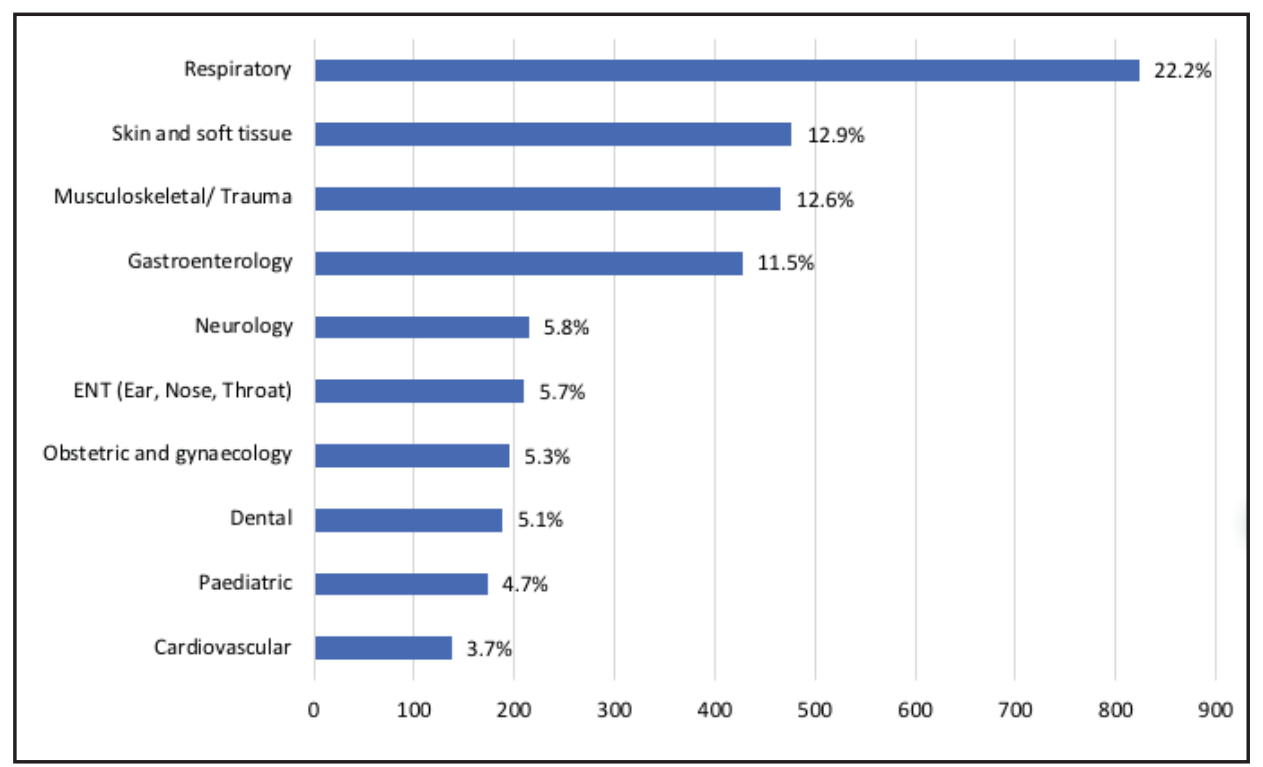

Figure 4: Breakdown of consultations seen in SAMS clinics categorized according to the main specialty of the presentation, including the 10 most frequent categories. Number of consultations ( $x$-axis) in each diagnostic category ( $y$-axis) and the proportion that each specialty represented (percentage) 


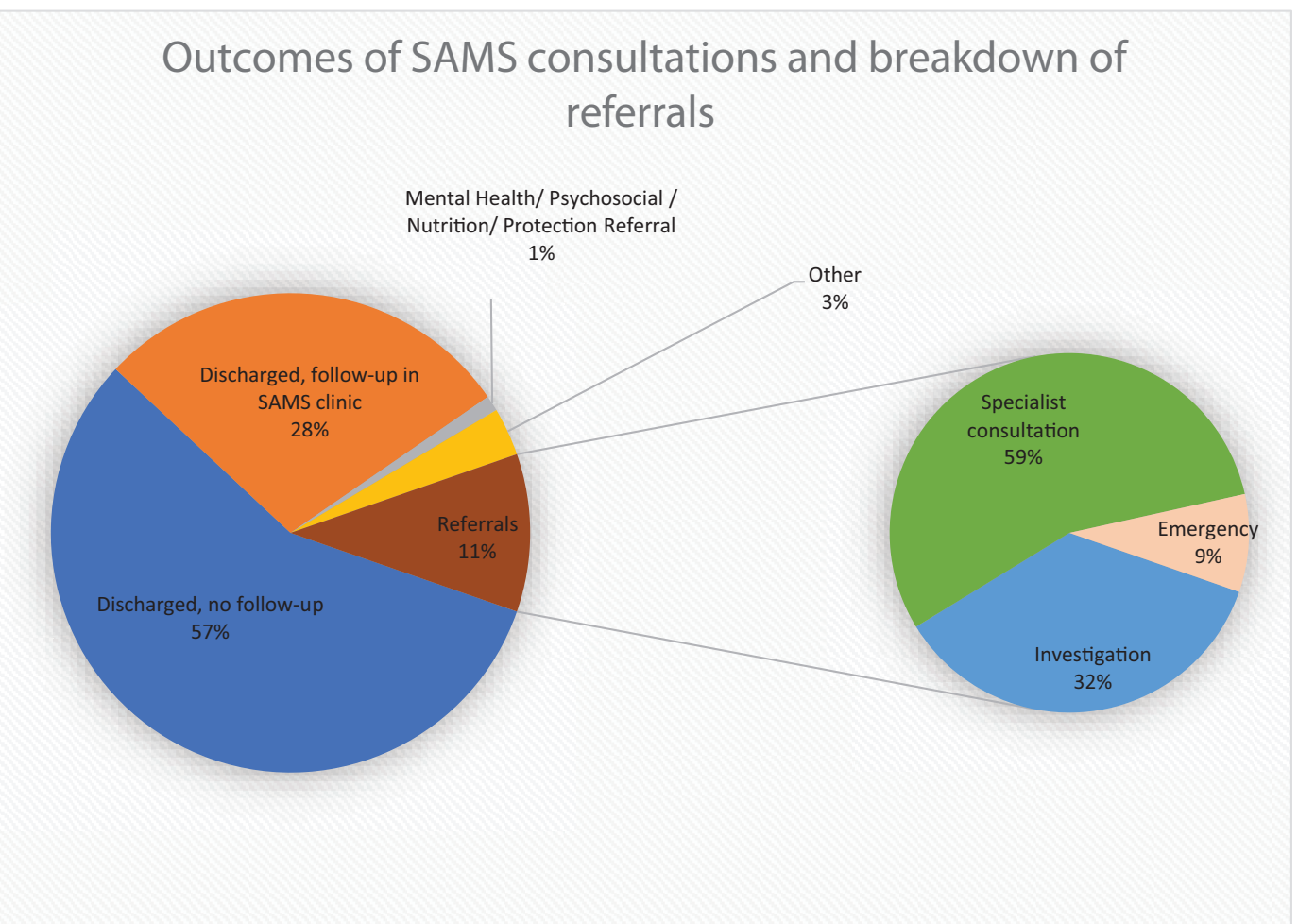

Figure 5: The outcome for the 4218 primary healthcare consultations made during the 8-month period in the SAMS clinics; 233 (11\%) required onward referral

category was musculoskeletal ( $12.6 \%$ of consultations) and included arthritis, back pain, and acute and traumatic injuries causing chronic pain. Gastrointestinal diagnoses including gastro-esophageal reflux disease, abdominal pain, and diarrheal illnesses (predominantly infectious) varied from $5 \%$ to $16 \%$ (average $11.5 \%$ ) in different months over the time period. Neurological conditions accounted for $5.8 \%$ of consultations-headache conditions, seizure disorders, and undiagnosed neurological symptoms, some of which had a suspected psychosocial component.

Obstetrics and gynecology issues accounted for 5\% of consultations. Visits included antenatal care, contraception and pre-conception planning, as well as gynecology complaints including vaginal discharge, pain and irregular bleeding, endometriosis, fibroids, and non-specific pelvic pain. Routine pediatric consultations for growth and nutrition accounted for $4.7 \%$ of the presentations, whereas acute presentations were coded differently under specialty, and children accounted for $42 \%$ of the total consultations. Mental health and psychosocial care accounted for $2.3 \%$ of the diagnoses made.

Over the time period of the study, the monthly percentage breakdown according to specialty was relatively consistent. Fluctuations were seen for respiratory consultations, peaking during the winter months with $28.9 \%$ of consultations respiratory in nature in December 2016 compared with
$12.3 \%$ of consultations in June 2017. Pediatric consultations also varied throughout the time period studied, ranging from $4.5 \%$ to $13.4 \%$ of consultations in different months.

\section{Outcomes}

Figure 5 displays the outcome of the consultations; Table 4 (see appendix) presents these outcomes by month. This shows that the majority of patients were discharged (57\%) or followed up in SAMS clinic (28\%). A small proportion (1\%) was referred to mental health or protection services and 3\% were classified as "other." 233 (11\%) resulted in onward referrals.

Out of the 233 (11\%) of referrals made, just over half were routine secondary care referrals. 125 were for investigations including blood tests, X-rays, ultrasounds, and other imaging, and 35 were emergency referrals into hospital.

Figure 6 and Table 5 show the breakdown of the referrals made. Dentistry was the most common, accounting for a quarter of all referrals despite only contributing to 5\% of consultations. Dental care during the time period was provided by a humanitarian organization delivering an outreach clinic.

Referrals to obstetrics and gynecology were the second largest group accounting for $9 \%$ of all referrals; this was mostly for routine antenatal blood tests and ultrasound 
Referrals for refugees into Greece's health system

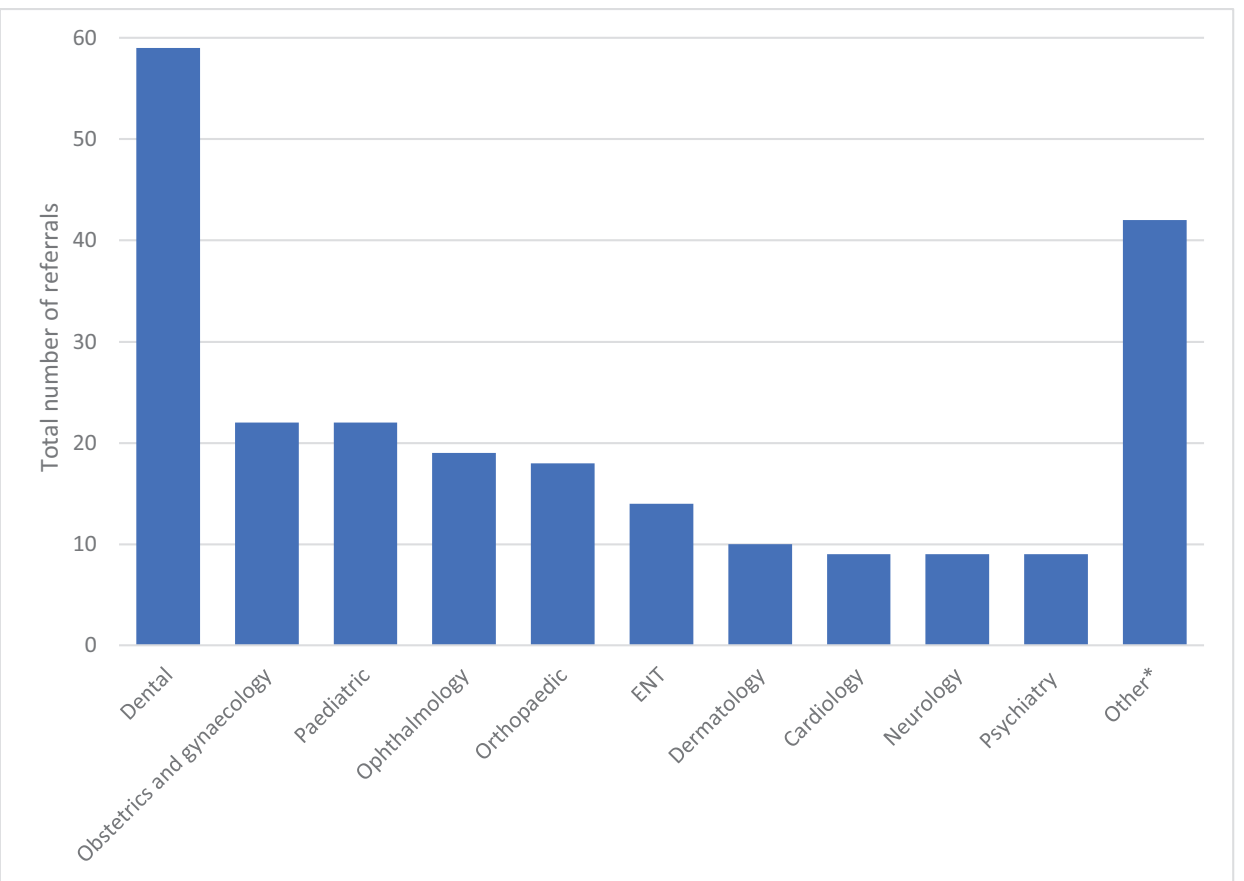

Figure 6: Specialty for the 233 consultations (out of 4218 during the 8-month period) which resulted in an onward referral. *Other includes gastroenterology, rheumatology, urology, endocrinology, surgery

scans and reflected adherence to both SAMS and international guidelines for the care of pregnant women. A further $9 \%$ of referrals were to pediatrics and reflected findings from active screening for childhood growth and development concerns.

\section{DISCUSSION}

This retrospective analysis of clinical consultations and onward referrals for refugees seen in SAMS clinics in northern Greece contributes to sparse literature on this topic. Of the 4218 consultations, those 17 years and under accounted for $42 \%$ of all consultations with half of these for children under 5 years. Overall, women account for $50 \%$ of attendances. Women and children represent 33\% and $21 \%$, respectively of camp residents, suggesting that they consult more frequently. ${ }^{[4]}$ The higher proportion of consultations within these two groups is likely due to high rates of infectious disease in children, antenatal care in women, with health seeking behaviors and gender roles in the household also likely to play a role. The proportion of the elderly (over 65 years) among the camp residences and consultations was very low, at $0.9 \%$, likely reflecting the rigors of making the sea and road journey required to arrive in Greece.

The poor living conditions within the camps ${ }^{[20]}$ could be potential contributors to the respiratory, gastrointestinal, and skin and soft tissue presentations seen in this cohort.
Refugees are living in cramped conditions in tents with often insufficient water and sanitation facilities and difficulties maintaining food hygiene; this could contribute to respiratory or gastrointestinal infections. There is a high prevalence of smoking among Syrians, particularly among men; as such, passive smoking together with indoor fires, unregulated cooking equipment, and cold and dusty conditions within the camps ${ }^{[21]}$ contributed to respiratory complaints.

Disrupted water supplies or unsanitary washing facilities exacerbated skin infections, bites, and cuts and meant that eradication of scabies and head lice was challenging, with reinfection common. Regarding scabies, studies in vulnerable populations have shown that a mass drug administration with ivermectin could reduce the risks of transmission; however, this intervention has not been tested among refugee populations in conditions similar to Greece. ${ }^{[22,23]}$

Acute infections accounted for $29 \%$ of the consultations. Infections were similar to what is seen in non-refugee populations; as such, concerns that refugees bring in infections that can affect host populations have been unfounded. ${ }^{[24]}$ Syrian and Iraqi populations have usually been vaccinated in their country of origin; however given the disrupted health systems from the protracted conflicts in the respective countries, vaccination rates would have been affected.

The proportion of consultations for chronic complaints remained constant throughout the time period assessed 
at around 25\% of consultations; among these were NCDs that are increasingly important in low- and middle-income countries and in Syria. ${ }^{[24-26]}$ The actual prevalence of NCDs in the camps is unknown; screening efforts were not systematic due to resource constraints, and population movements meant that follow-up was challenging. NCD screening and management is an important public health measure, ${ }^{[27,28]}$ but is often neglected in favor of more acute needs.

Fluctuations over the study period were seen, most frequently in respiratory complaints and in pediatric consultations. These could be seasonal or weather-related as has been reported in refugee populations before ${ }^{[29]}$; however, these also reflect the disruption of camps and subsequent movements of SAMS into new locations. New relationships had to be cultivated in order to gain access and trust with not only the refugee community but also in setting up referral pathways with local hospitals and services, leading to a transient drop in consultations. This gives an insight into the challenges of providing stable PHC services in this situation.

\section{Referrals}

Part of the aim of SAMS was to reduce the impact of refugees on the Greek healthcare system during the time of high entry of refugees through its borders and to relieve pressure on already strained services. Therefore, specialists were recruited as volunteers to allow for some specialist care to occur in clinic. There were still referrals into secondary care, but only $6 \%$ for specialist consultation. It is likely that ensuring recruitment of volunteer specialists had an impact on reducing pressure on the Greek health system, though this could not be proven with the current study.

Dental care accounted for $5 \%$ of the consultations but $25 \%$ of referrals. Dental care is not included in documents such as the Sphere Handbook, ${ }^{[30]}$ which provides minimum standards of health to be adhered to in humanitarian responses, and is thus often overlooked in healthcare servicing, although it is recognized as a cause of morbidity and malnutrition risk. ${ }^{[31,32]}$ In the camps in which SAMS provided humanitarian care, dental care was provided as outreach by other humanitarian organizations.

Obstetrics and gynecology and pediatrics were also frequent reasons for referral ( $9 \%$ each). SAMS usually had these specialists volunteering which allowed for specialist consultations to be provided in clinic. As such, referrals were often for particular investigations or interventions beyond the scope of the clinic, e.g. antenatal fetal ultrasound. ${ }^{[33]}$

The proportion of MHPSS referrals was 4\%. MHPSS has been highlighted as a key gap in both the academic and gray literature and presents context-specific challenges. MHPSS in Greece, even for Greek nationals, is under-resourced and there were few culturally appropriate provisions for refugees. ${ }^{[15]}$ The MHPSS burden for refugees is high and multifactorial, ${ }^{[10]}$ exacerbated by slow and burdensome asylum procedures and the lack of high quality, culturally appropriate MHPSS programs across Greece. ${ }^{[34]}$ MHPSS mostly manifested as depression, anxiety, some posttraumatic stress disorders, and psychosomatic complaints, e.g. abdominal pain and headaches. Our referrals are unlikely to reflect the true burden, due to stigma around discussion and presentation of mental health, and psychosomatic complaints being possibly coded as physical complaints.

\section{Limitations}

The analysis presented uses routinely collected data at a time of frequent movement of refugees. SAMS began providing PHC for refugees in Greece in established camps in May 2016; however as they were moved out, numbers of refugees in these camps and consultations were affected until early 2017 . We provide data from a single period during the refugee crisis, in a specific region, representing the experiences of a single humanitarian organization.

An electronic health record for data collection was used, and though volunteers were trained in its use and a data volunteer was present through the period, there may be differences in the way presentations were interpreted and coded. Moreover, some data were incomplete. Unfortunately, it was not possible to look at some potentially interesting trends in data, such as categorizing consultations according to gender, due to software design limitations.

We indicate the proportion and specialty for referral, but further work to explore the outcome of secondary care referrals (for example, admissions) is key as frustrations were often expressed regarding waiting times, lack of translators, and transportation logistics. This is similar to settings where language differences impact healthcare access, ${ }^{[35]}$ but differs from other refugee hosting settings where a shared language and culture exists, even when other barriers to healthcare access remain. ${ }^{[36]}$

\section{CONCLUSION}

Effective PHC provision by humanitarian organizations reduces specialist referrals into the Greek health system, particularly where volunteer specialists (notably pediatricians and obstetricians and gynecologists) are embedded in the PHC clinic. The proportion of referrals for dentistry highlights the need for dental services in refugee populations, the morbidity among refugees, and the need 
for more consistent provision for refugee dental health. Population movements posed challenges for SAMS but also opportunities to adapt how PHC was delivered to refugees. Earlier communication from authorities and improved coordination mechanisms to minimize redundancy and gaps in healthcare delivery would have improved patient care handover at their next destination.

Refugee healthcare provision remains challenging at a time when Greece continues to experience an economic crisis and difficulties providing healthcare for its own population. Integration of refugee healthcare into the Greek health system avoids the establishment of a parallel health system, but requires further investment in Greece's health system to provide standardized and cost-effective approach to $\mathrm{PHC}$, specialist referrals, and adequate healthcare delivery for both refugees and the local population. In the meantime, humanitarian organizations remain critical in relieving pressure from Greek health services, as high numbers of refugees continue residing in Greece, many still encamped, resulting in maintained pressure on local health systems.

\section{Criteria for inclusion}

These include substantial contributions to concept and design of study or acquisition of data or analysis and interpretation of data; drafting the article or revising it critically; final approval of the version to be published.

\section{Declarations}

The manuscript has been read and approved by all the authors, the requirements for authorship have been met, and each author believes that the manuscript represents honest work.

\section{Acknowledgments}

We would like to thank the translators and health professionals who volunteered with SAMS, SAMS staff in Greece, and the staff in SAMS headquarters USA.

\section{Financial support and sponsorship}

Nil.

\section{Conflicts of interest}

There are no conflicts of interest.

\section{References}

1. UNHCR - The UN Refugee Agency. Greece Sea Arrivals Dashboard [cited July 21, 2018]. 2017. Available from: https://data2.unhcr.org/en/ documents/download/61492. [Last accessed on 2018 Jul 21].

2. Economou C. Greece: Health system review. Health Syst Transit 2010;12:1-177, xv-xvi.

3. UNHCR-The UN Refugee Agency. Europe Refugee Emergency, Site locations in Greece [cited July 21, 2018]. 2016. Available from: https:// data2.unhcr.org/en/documents/download/47234. [Last accessed on 2018 Jul 21].

4. UNHCR-The UN Refugee Agency. Greece Fact Sheet 1-31 December 2020 [cited February 15, 2021]. 2020. Available from: https://data2. unhcr.org/en/documents/details/84481. [Last accessed on 2020 Apr 14].

5. Kotsiou OS, Kotsios P, Srivastava DS, Kotsios V, Gourgoulianis KI, Exadaktylos AK. Impact of the refugee crisis on the Greek healthcare system: A long road to Ithaca. Int J Environ Res Public Health 2018;15:1790.

6. Bradbury H, Lebano A, Hamed S, Gil-Salmeron A, Dura-Ferrandis E, Garces-Ferrer J, et al. Policy makers', NGO, and healthcare workers' accounts of migrants' and refugees' healthcare access across EuropeHuman rights and citizenship based claims. Front Sociol 2020;5:6-7.

7. UNHCR-The UN Refugee Agency. Greece Aegean Islands weekly snapshot 17-23rd February 2020 [cited April 14, 2020]. 2020. Available from UNHCR Operation Portal Greece: https://data2.unhcr.org/en/ documents/download/74227. [Last accessed on 2020 Apr 14].

8. Mossialos EA. Analysing the Greek health system: A tale of fragmentation and inertia. Health Econ 2005;14:151-68.

9. Kitching GT, Haavik HJ, Tandstad BJ, Zaman M, Darj E. Exploring the role of ad hoc grassroots organizations providing humanitarian aid on Lesvos, Greece. PLoS Curr 2016;8:3.

10. Ben Farhat J, Blanchet K, Juul Bjertrup P, Veizis A, Perrin C, Coulborn RM, et al. Syrian refugees in Greece: Experience with violence, mental health status, and access to information during the journey and while in Greece. BMC Med 2018;16:40.

11. Gunst M, Jarman K, Yarwood V, Rokadiya S, Capsaskis L, Orcutt M, et al. Healthcare access for refugees in Greece: Challenges and opportunities. Health Policy 2019;123:818-24.

12. Paraskeva M, Bogeas T. Access to health is a luxury for stranded refugees in Greece. European Public Health Alliance [cited April 12, 2020]. 2020. Available from: https://epha.org/access-to-health-is-a-luxury-forstranded-refugees-in-greece/. [Last accessed on 2020 Apr 12].

13. Hémono R. "The needs have clearly evolved as time has gone on.": A qualitative study to explore stakeholders' perspectives on the health needs of Syrian refugees in Greece following the 2016 European UnionTurkey agreement. Conflict Health 2018;12:5-6.

14. Joseph L, Ismail S, Prior D, Gunst M, Jarman K, Harris M, et al. Barriers to healthcare access for refugees in Greece. Eur J Public Health 2018;28:407.

15. Christodoulou GN, Abou-Saleh MT. Greece and the refugee crisis: Mental health context. BJPsych Int 2016;13:89-91.

16. European Commission. EU launches new humanitarian programme for the integration and accommodation of refugees in Greece. [cited July 21, 2018]. 2017. Available from: https://ec.europa.eu/echo/ news/eu-launches-new-humanitarian-programme-integration-andaccommodation-refugees-greece_en. [Last accessed on 2018 Jul 21].

17. Ministry of Health of Greece Hellenic Center for Disease Control and Prevention and WHO Regional Office for Europe. Greece: Assessing health-system capacity to manage large influxes of migrants (W. H. Europe, Ed.) [cited July 21, 2018]. 2015. Available from: Joint report on a mission of the Ministry of Health of Greece Hellenic Center for Disease Control and Prevention and WHO Regional Office for Europe. Available from: http://www.euro.who.int/_data/assets/pdf_file/0007/300400/ Greece-Assessment-Report-en.pdf?ua=1. [Last accessed on 2018 Jul 21].

18. Hellenic Centre for Disease Control and Prevention (KEELPNO). Ministry of Health. [cited July 21, 2018]. 2018. Available from: http://www. keelpno.gr.

19. Ministry of Health—National Health Operations Centre. E.K.E.P.Y Refugee Camps in Greece on 13/09/2017 (N. T. Geospatial Analysis and GIS Research Group, Producer). Retrieved April 10, 2019, from E.K.E.P.Y Refugee Camps in Greece on September 13, 2017. 2016. Available from: http://geochoros. survey.ntua.gr/ekepy/. [Last accessed on 2020 Apr 10].

20. Human Rights Watch. Greece: Refugee "hotspots" unsafe, unsanitary. Women, children fearful, unprotected; lack basic shelter [cited July 
21, 2018]. 2016. Available from: https:/www.hrw.org/news/2016/05/19/ greece-refugee-hotspots-unsafe-unsanitary. [Last accessed on 2018 Jul 21].

21. Abdulrahim $S$, Jawad $M$. Socioeconomic differences in smoking in Jordan, Lebanon, Syria, and Palestine: A cross-sectional analysis of national surveys. PLoS One 2018;13:e0189829.

22. Kearns TM, Speare R, Cheng AC, McCarthy J, Carapetis JR, Holt DC, et al. Impact of an ivermectin mass drug administration on scabies prevalence in a remote Australian aboriginal community. Plos Negl Trop Dis 2015;9:e0004151.

23. Romani L, Whitfeld MJ, Koroivueta J, Kama M, Wand H, Tikoduadua L, et al. Mass drug administration for scabies control in a population with endemic disease. N Engl J Med 2015;373:2305-13.

24. World Health Organization WHO, r. o. Migration and health: Key issues. [cited July 21, 2018]. 2018. Available from: http://www.euro.who.int/ en/health-topics/health-determinants/migration-and-health/migranthealth-in-the-european-region/migration-and-health-key-issues\# . [Last accessed on 2018 Jul 21].

25. Rahim HF, Sibai A, Khader Y, Hwalla N, Fadhil I, Alsiyabi H, et al. Noncommunicable diseases in the Arab world. Lancet 2014;383:356-67.

26. World Health Organization. Non-communicable diseases (NCD) country profiles. Syrian Arab Republic. 2014. [cited July 21, 2018]. Available from: http://www.who.int/nmh/countries/syr_en.pdf?ua=1. [Last accessed on 2018 Jul 21].

27. Yun K, Hebrank K, Graber LK, Sullivan MC, Chen I, Gupta J. High prevalence of chronic non-communicable conditions among adult refugees: Implications for practice and policy. J Community Health 2012;37:1110-8.

28. Ruby A, Knight A, Perel P, Blanchet K, Roberts B. The effectiveness of interventions for non-communicable diseases in humanitarian crises: A systematic review. PLoS One 2015;10:e0138303.
29. Terkawi AS, Bakri B, Alsadek AS, al-Hasan AH, Alrahhal MS, Alsaleh FM, et al. Child and adolescent health in northwestern Syria: Findings from Healthy-Syria 2017 study. Avicenna J Med 2019;9:61-74. [cited 2020 September 17]. Available from: http:/www.avicennajmed.com/article. asp? issn $=2231-0770$; year $=2019 ;$ volume $=9 ;$ issue $=2 ;$ spage $=61$; epa ge $=74$; aulast $=$ Terkawi.

30. Sphere Project. Sphere handbook: Humanitarian charter and minimum standards in disaster response. [cited September 17, 2020]. 2011. Available at: https:/handbook.spherestandards.org/en/sphere/\#ch001. [Last accessed on 2020 Sep 17].

31. Petersen PE, Bourgeois D, Ogawa H, Estupinan-Day S, Ndiaye C. The global burden of oral diseases and risks to oral health. Bull World Health Organ 2005;83:661-9.

32. Linden GJ, Lyons A, Scannapieco FA. Periodontal systemic associations: Review of the evidence. J Periodontol 2013;84:S8-19.

33. World Health Organisation. WHO recommendations on antenatal care for a positive pregnancy experience: Summary. [cited July 21, 2018]. 2018. Available from: http://apps.who.int/iris/bitstream/handle/10665/259946/ WHO-RHR-18.01-eng.pdf;jsessionid=ABF749EE0638A81C1D954ACE48 CD8C2D? sequence $=1$. [Last accessed on 2018 Jul 21].

34. Medecins sans Frontieres. Greece in 2016: Vulnerable people get left behind. [cited July 21, 2018]. 2016. Available from: https://www.msf. org/sites/msf.org/files/report_vulnerable_people_201016_eng.pdf. [Last accessed on $2018 \mathrm{Jul} 21$ ].

35. Robertshaw L, Dhesi S, Jones LL. Challenges and facilitators for health professionals providing primary healthcare for refugees and asylum seekers in high-income countries: A systematic review and thematic synthesis of qualitative research. BMJ Open 2017;7:e015981.

36. Blanchet K, Fouad FM, Pherali T. Syrian refugees in Lebanon: The search for universal health coverage. Confl Health 2016;10:12. 


\begin{tabular}{|c|c|c|c|c|c|}
\hline Visit month & Infants $0-4$ years & Children $5-17$ years & Adults $18-65$ years & Elderly 66+ years & Total \\
\hline Dec-16 & $273(24.3 \%)^{*}$ & $210(18.7 \%)$ & $636(56.7 \%)$ & $3(0.3 \%)$ & 1122 \\
\hline Jan-17 & 146 (22.2\%) & 127 (19.3\%) & $38 \mathrm{I}(57.8 \%)$ & $5(0.8 \%)$ & 659 \\
\hline Feb- 17 & 50 (I8.9\%) & $61(23.0 \%)$ & I53 (57.7\%) & I (0.4\%) & 265 \\
\hline Mar-17 & $40(21.2 \%)$ & 30 (I5.9\%) & $114(60.3 \%)$ & $5(2.6 \%)$ & 189 \\
\hline Apr-17 & $104(18.6 \%)$ & 145 (26.0\%) & $305(54.7 \%)$ & $4(0.7 \%)$ & 558 \\
\hline May-17 & II 2 (20.7\%) & 114 (21.1\%) & $310(57.3 \%)$ & $5(0.9 \%)$ & 541 \\
\hline Jun-I7 & 66 (I8.9\%) & 90 (25.7\%) & $188(53.7 \%)$ & $6(1.7 \%)$ & 350 \\
\hline Jul- I7 & $89(18.4)$ & 99 (20.5\%) & 289 (59.7\%) & 7 (1.4\%) & 484 \\
\hline Total & $880(21.1 \%)$ & $876(21 \%)$ & $2376(57 \%)$ & $36(0.9 \%)$ & 4168 \\
\hline
\end{tabular}

*Percentage of total per month

\begin{tabular}{|c|c|c|c|c|c|c|c|c|c|}
\hline & $\begin{array}{c}\text { Dec-16 } \\
(N=1129) \\
\end{array}$ & $\begin{array}{c}\text { Jan- } 17 \\
(N=667)\end{array}$ & $\begin{array}{c}\text { Feb-17 } \\
(N=259)\end{array}$ & $\begin{array}{c}\text { Mar-17 } \\
(N=191) \\
\end{array}$ & $\begin{array}{c}\text { Apr-17 } \\
(N=519)\end{array}$ & $\begin{array}{l}\text { May- } 17 \\
(N=436)\end{array}$ & $\begin{array}{c}\text { Jun- } 17 \\
(N=295) \\
\end{array}$ & $\begin{array}{c}\text { Jul-17 } \\
(N=423)\end{array}$ & $\begin{array}{c}\text { Totals } \\
(\mathrm{N}=3919) \\
\end{array}$ \\
\hline Acute infection & 407 (36.0\%) & $213(31.9 \%)$ & 88 (34.0\%) & 43 (22.5\%) & $115(22.2 \%)$ & $112(25.7 \%)$ & $64(21.7 \%)$ & 104 (24.6\%) & II 46 (29.2\%) \\
\hline Chronic condition & 280 (24.8\%) & 161 (24.1\%) & $65(25.1 \%)$ & $53(27.7 \%)$ & $139(26.8 \%)$ & I $23(28.2 \%)$ & $76(25.8 \%)$ & $106(25.1 \%)$ & $1003(25.6 \%)$ \\
\hline Acute: other & 177 (I5.7\%) & 91 (13.6\%) & $52(20.1 \%)$ & $44(23.0 \%)$ & $142(27.4 \%)$ & 87 (20.0\%) & $86(29.2 \%)$ & 123 (29.1\%) & $802(20.5 \%)$ \\
\hline Other* & 140 (12.4\%) & 94 (14.1\%) & $24(9.3 \%)$ & 32 (16.8\%) & 83 (16.0\%) & 78 (17.9\%) & 46 (I5.6\%) & 55 (I3.0\%) & 552 (14.1\%) \\
\hline Medication refill & 40 (3.5\%) & $63(9.4 \%)$ & $22(8.5 \%)$ & II (5.8\%) & 20 (3.9\%) & 21 (4.8\%) & 14 (4.7\%) & $20(4.7 \%)$ & $211(5.4 \%)$ \\
\hline Wound care & 58 (5.1\%) & 32 (4.8\%) & 7 (2.7\%) & $5(2.6 \%)$ & $12(2.3 \%)$ & 10 (2.3\%) & 7 (2.4\%) & $12(2.8 \%)$ & 143 (3.6\%) \\
\hline $\begin{array}{l}\text { Acute surgical } \\
\text { problem** }\end{array}$ & 27 (2.4\%) & 13 (1.9\%) & I (0.4\%) & $3(1.6 \%)$ & 8 (1.5\%) & 5 (I.I\%) & $2(0.7 \%)$ & $3(0.7 \%)$ & $62(1.6 \%)$ \\
\hline
\end{tabular}

Table 3: Diagnostic category of the consultations

\begin{tabular}{|c|c|c|c|c|c|c|c|c|c|}
\hline & $\begin{array}{c}\text { Dec-16 } \\
(N=1194)\end{array}$ & $\begin{array}{c}J a n-17 \\
(N=687)\end{array}$ & $\begin{array}{c}\text { Feb- } 17 \\
(N=279)\end{array}$ & $\begin{array}{l}\text { Mar- } 17 \\
(N=205)\end{array}$ & $\begin{array}{c}\text { Apr-17 } \\
(N=547)\end{array}$ & $\begin{array}{l}\text { May- } 17 \\
(N=492)\end{array}$ & $\begin{array}{l}\text { Jun-17 } \\
(N=330)\end{array}$ & $\begin{array}{c}\text { Jul-I } 7 \\
(N=443)\end{array}$ & $\begin{array}{c}\text { Totals } \\
(\mathrm{N}=4 \mid 77)\end{array}$ \\
\hline Respiratory & 303 (28.9\%) & I44 (23.6\%) & 7I (28.7\%) & $26(13.8 \%)$ & 99 (20.4l\%) & 81 (I8.4\%) & 35 (I2.3\%) & 64 (I5.9\%) & $823(22.2 \%)$ \\
\hline $\begin{array}{l}\text { Skin and soft } \\
\text { tissue }\end{array}$ & 144 (I3.7\%) & $83(13.6 \%)$ & 27 (10.9\%) & $23(12.2 \%)$ & 70 (I4.4\%) & $28(6.4 \%)$ & 35 (I2.3\%) & 67 (16.7\%) & 477 (12.9\%) \\
\hline $\begin{array}{l}\text { Musculoskeletal/ } \\
\text { trauma }\end{array}$ & 104 (9.9\%) & 83 (I3.6\%) & $33(13.4 \%)$ & I 8 (9.5\%) & 65 (I3.4\%) & 80 (18.2\%) & $36(12.7 \%)$ & 47 (II.7\%) & 466 (12.6\%) \\
\hline Gastroenterology & 115 (II.0\%) & $64(10.5 \%)$ & 40 (16.2\%) & $23(12.2 \%)$ & $28(5.8 \%)$ & 57 (I3.0\%) & 39 (I3.7\%) & $6 \mathrm{I}(15.2 \%)$ & 427 (II.5\%) \\
\hline Neurology & $54(5.1 \%)$ & $36(5.9 \%)$ & $24(9.7 \%)$ & $12(6.3 \%)$ & 36 (7.4\%) & $18(4.1 \%)$ & $13(4.6 \%)$ & 21 (5.2\%) & $214(5.8 \%)$ \\
\hline $\begin{array}{l}\text { ENT (ear, nose, } \\
\text { throat) }\end{array}$ & 59 (0.7\%) & $30(4.9 \%)$ & II (4.5\%) & $16(8.5 \%)$ & 20 (4.1\%) & $29(6.6 \%)$ & 19 (6.7\%) & 26 (6.5\%) & $210(5.7 \%)$ \\
\hline $\begin{array}{l}\text { Obstetrics and } \\
\text { gynecology }\end{array}$ & $50(4.8 \%)$ & $20(3.3 \%)$ & $8(3.2 \%)$ & $12(6.3 \%)$ & $23(4.7 \%)$ & $21(4.8 \%)$ & $15(5.3 \%)$ & 46 (II.4\%) & 195 (5.3\%) \\
\hline Dental & $40(3.8 \%)$ & 27 (4.4\%) & 7 (2.8\%) & I 4 (7.4\%) & $39(8.0 \%)$ & $32(7.3 \%)$ & 14 (4.9\%) & I 5 (3.7\%) & I88 (5.1\%) \\
\hline Pediatric & 47 (4.5\%) & $37(6.1 \%)$ & 4 (1.6\%) & 4 (2.1\%) & $29(6.0 \%)$ & $9(2.0 \%)$ & 38 (I3.4\%) & $5(1.2 \%)$ & 173 (4.7\%) \\
\hline Cardiovascular & 44 (4.2\%) & $17(2.8 \%)$ & $5(2.0 \%)$ & $12(6.3 \%)$ & 27 (5.6\%) & $19(4.3 \%)$ & $7(2.5 \%)$ & 6 (1.5\%) & 137 (3.7\%) \\
\hline $\begin{array}{l}\text { Genitourinary/ } \\
\text { renal }\end{array}$ & $24(2.3 \%)$ & $22(3.6 \%)$ & $12(4.9 \%)$ & $5(2.6 \%)$ & $25(5.2 \%)$ & $19(4.3 \%)$ & 9 (3.2\%) & $18(4.5 \%)$ & I34 (3.6\%) \\
\hline Healthy adult/child & $26(2.5 \%)$ & $7(1.1 \%)$ & $7(2.8 \%)$ & 12 (6.3\%) & $23(4.7 \%)$ & $4(0.9 \%)$ & $18(6.3 \%)$ & $5(1.2 \%)$ & $102(2.8 \%)$ \\
\hline Endocrine & 35 (3.3\%) & $22(3.6 \%)$ & $6(2.4 \%)$ & $8(4.2 \%)$ & I3 (2.7\%) & $3(0.7 \%)$ & $6(2.1 \%)$ & $3(0.7 \%)$ & $96(2.6 \%)$ \\
\hline Eye & 33 (3.1\%) & $13(2.1 \%)$ & $9(3.6 \%)$ & $6(3.2 \%)$ & $10(2.1 \%)$ & $10(2.3 \%)$ & $3(1.1 \%)$ & 4 (1.0\%) & $88(2.4 \%)$ \\
\hline $\begin{array}{l}\text { Mental health/ } \\
\text { social/protection }\end{array}$ & $22(2.1 \%)$ & $10(1.6 \%)$ & $7(2.8 \%)$ & $5(2.6 \%)$ & $9(1.9 \%)$ & 14 (3.2\%) & $9(3.2 \%)$ & II (2.7\%) & $87(2.3 \%)$ \\
\hline Other* & 79 (7.5\%) & $60(9.9 \%)$ & $5(2.0 \%)$ & $8(4.2 \%)$ & $21(4.3 \%)$ & $6 \mathrm{I}(13.9 \%)$ & $29(10.2 \%)$ & 30 (7.5\%) & 293 (7.9\%) \\
\hline Total & 1194 & 687 & 279 & 205 & 547 & 492 & 330 & 443 & 4177 \\
\hline
\end{tabular}


Yarwood, et al.: Referrals for refugees into Greece's health system

\begin{tabular}{|c|c|c|c|c|c|c|c|c|c|}
\hline Visit month & $\begin{array}{l}\text { Dec- } 16 \\
N=1050\end{array}$ & $\begin{array}{l}J a n-17 \\
N=605\end{array}$ & $\begin{array}{l}\text { Feb- } 17 \\
N=246\end{array}$ & $\begin{array}{l}\text { Mar- } 17 \\
N=188\end{array}$ & $\begin{array}{l}\text { Apr- } 17 \\
N=473\end{array}$ & $\begin{array}{l}\text { May- } 17 \\
N=406\end{array}$ & $\begin{array}{l}\text { Jun- } 17 \\
N=280\end{array}$ & Jul- I 7 N=399 & $\begin{array}{c}\text { Total } \\
N=3647\end{array}$ \\
\hline Discharged, no follow-up & $539(5 \mathrm{I} .3 \%)$ & $343(56.7 \%)$ & I 37 (55.7\%) & $98(52.1 \%)$ & $293(61.9 \%)$ & $276(68.0 \%)$ & $172(6 \mid .4 \%)$ & $259(64.9 \%)$ & $2117(58.0 \%)$ \\
\hline $\begin{array}{l}\text { Discharged, follow-up in } \\
\text { SAMS clinic }\end{array}$ & 403 (38.4\%) & $190(31.4 \%)$ & $78(31.7 \%)$ & $67(35.6 \%)$ & $108(22.8 \%)$ & 75 (18.5\%) & $67(23.9 \%)$ & 74 (I8.5\%) & $1062(29.1 \%)$ \\
\hline $\begin{array}{l}\text { Referral (investigations, } \\
\text { specialist, or emergency, } \\
\text { sent to hospital) }\end{array}$ & $106(10.1 \%)$ & $69(11.4 \%)$ & $27(11.0 \%)$ & $24(12.8 \%)$ & $53(11.2 \%)$ & $36(8.9 \%)$ & $25(8.9 \%)$ & $53(13.3 \%)$ & $393(10.8 \%)$ \\
\hline $\begin{array}{l}\text { Mental health/psychoso- } \\
\text { cial/nutrition/protection } \\
\text { referral }\end{array}$ & II (I.0\%) & $2(0.3 \%)$ & I $(0.4 \%)$ & $0(0.0 \%)$ & $5(1.1 \%)$ & $9(2.2 \%)$ & $7(2.5 \%)$ & $4(1.0 \%)$ & $39(1.1 \%)$ \\
\hline Other & $23(2.2 \%)$ & $12(2.0 \%)$ & $8(3.3 \%)$ & $3(1.6 \%)$ & $23(4.9 \%)$ & 19 (4.7\%) & II (3.9\%) & 22 (5.5\%) & $|2|$ (3.3\%) \\
\hline
\end{tabular}

\begin{tabular}{|c|c|c|c|c|c|c|c|c|c|}
\hline & $\begin{array}{c}\text { Dec- } 16 \\
N=57\end{array}$ & $\begin{array}{c}\text { Jan- } 17 \\
N=41\end{array}$ & $\begin{array}{c}\text { Feb- } 17 \\
N=15\end{array}$ & $\begin{array}{c}\text { Mar- } 17 \\
N=13\end{array}$ & $\begin{array}{c}\text { Apr-17 } \\
N=39\end{array}$ & $\begin{array}{c}\text { May- } 17 \\
N=23\end{array}$ & $\begin{array}{l}\text { Jun-17 } \\
N=12\end{array}$ & Jul- I7 N=| 3 & $\begin{array}{c}\text { Total } \\
N=233\end{array}$ \\
\hline Dental & $18(31.6 \%)$ & 14 (34.1\%) & $5(33.3 \%)$ & $6(46.2 \%)$ & $12(30.8 \%)$ & $0(0.0 \%)$ & $0(0.0 \%)$ & $4(12.1 \%)$ & $59(25.3 \%)$ \\
\hline $\begin{array}{l}\text { Obstetrics and } \\
\text { gynecology }\end{array}$ & $4(7.0 \%)$ & $3(7.3 \%)$ & I (6.7\%) & $2(15.4 \%)$ & 5 (I2.8\%) & $2(8.7 \%)$ & $0(0.0 \%)$ & $5(15.2 \%)$ & $22(9.4 \%)$ \\
\hline Pediatric & $5(8.8 \%)$ & $4(9.8 \%)$ & $2(13.3 \%)$ & $0(0.0 \%)$ & $4(10.3 \%)$ & $6(26.1 \%)$ & I (8.3\%) & $0(0.0 \%)$ & 22 (9.4\%) \\
\hline Ophthalmology & 7 (I2.3\%) & $3(7.3 \%)$ & $3(20.0 \%)$ & $2(15.4 \%)$ & $3(7.7 \%)$ & $0(0.0 \%)$ & $0(0.0 \%)$ & I (3.0\%) & 19 (8.2\%) \\
\hline Orthopedic & I (I.8\%) & $4(9.8 \%)$ & $0(0.0 \%)$ & I (7.7\%) & $3(7.7 \%)$ & 4 (17.4\%) & I (8.3\%) & $4(12.1 \%)$ & 18 (7.7\%) \\
\hline ENT & $5(8.8 \%)$ & $2(4.9 \%)$ & I (6.7\%) & $0(0.0 \%)$ & I (2.6\%) & I (4.3\%) & I (8.3\%) & $3(9.1 \%)$ & 14 (6.0\%) \\
\hline Dermatology & $5(8.8 \%)$ & $0(0.0 \%)$ & $0(0.0 \%)$ & I (7.7\%) & $0(0.0 \%)$ & I (4.3\%) & $2(16.7 .0 \%)$ & I (3.0\%) & 10 (4.3\%) \\
\hline Cardiology & $2(3.5 \%)$ & $0(0.0 \%)$ & I (6.7\%) & $0(0.0 \%)$ & $2(5.1 \%)$ & I (4.3\%) & $0(0.0 \%)$ & $3(9.1 \%)$ & $9(3.9 \%)$ \\
\hline Neurology & $3(5.3 \%)$ & $2(4.9 \%)$ & $0(0.0 \%)$ & $0(0.0 \%)$ & $0(0.0 \%)$ & $0(0.0 \%)$ & I (8.3\%) & $3(9.1 \%)$ & 9 (3.9\%) \\
\hline Psychiatry & $3(5.3 \%)$ & I (2.4\%) & $0(0.0 \%)$ & $0(0.0 \%)$ & $0(0.0 \%)$ & I (4.3\%) & I (I0.0\%) & $3(9.1 \%)$ & 9 (3.9\%) \\
\hline Other* & $4(7.0 \%)$ & $8(19.5 \%)$ & $2(13.3 \%)$ & I (7.7\%) & $9(23.1 \%)$ & 7 (30.4\%) & 5 (4I.7\%) & $6(18.2 \%)$ & 42 (I8.0\%) \\
\hline
\end{tabular}

*Other includes: gastroenterology, rheumatology, urology, endocrinology, surgery 